\title{
Application of Bryophytes and Glass Pumice in Northern China LID Landscape Design
}

\author{
Danning $\operatorname{Han}^{1, a}$ \\ ${ }^{1}$ Liaocheng University,Liaocheng, China \\ ahandanning@yeah.net
}

Key words: bryophytes; glass pumice; ecological landscape design

\begin{abstract}
Based on analyzing the climatic conditions of northern China, the physiological properties of bryophytes and the features of glass pumice, this article proved the feasibility of using bryophytes and glass pumice for northern landscaping, and put forward application methods of bryophytes and glass pumice in LID landscape design.
\end{abstract}

\section{Introduction}

Due to climate characteristics, economic, low quality of ecological infrastructure construction and other factors, the ecosystem of northern China degenerated seriously. Increasing urban wetlands such as ecological parks, can improve the ecological environment effectively. Therefore, landscape design based on low-impact development (LID) becomes very important. Using bryophytes and glass pumice in northern landscaping as a new method of LID landscape design is worth researching.

\section{The necessity of LID landscape design in northern China}

The decrease of rainwater is adverse to the maintenance of urban wetlands. Take the typical northern cities Jinan and Shijiazhuang as an example, Fig. 1 shows that the annual precipitation of these two cities showed obvious decreasing trend in recent years. Based on LID design, urban ecological wetlands could intercept more rainwater than ordinary landscape facilities. Therefore, LID landscape design is very significant in northern China.
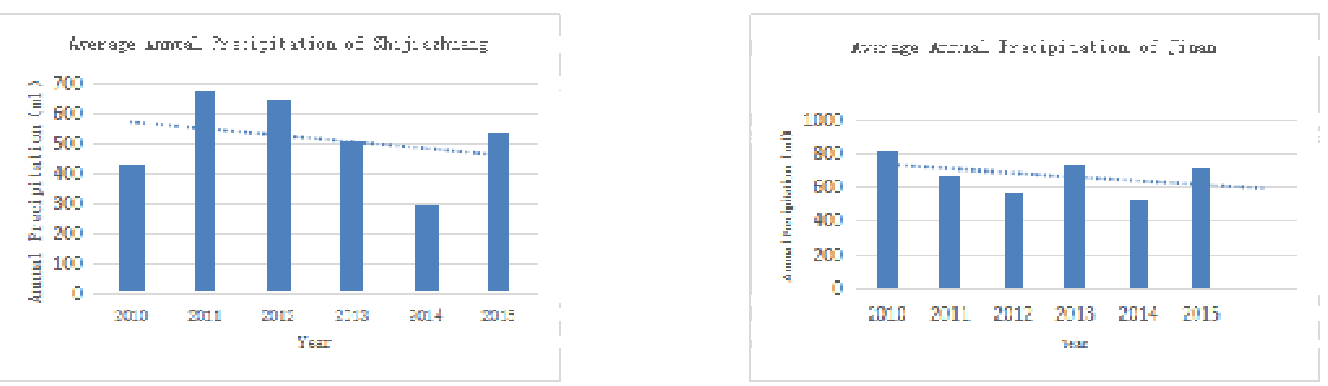

Figure 1 Average Annual Precipitation of Shijiazhuang and Jinan [ml] 


\section{The feasibility of application of bryophytes and glass pumice in LID landscape design of northern China}

\section{Properties and advantages of bryophytes.}

Water holding.Bryophytes are small green plants that they only have stems and leaves, but no real roots and vascular bundles [1].They are usually found as ground cover in the wild. Bryophytes have a strong capability of water holding, the maximum water storage capability can reach 5 times of their own dry weight [2].

Soil conservation.Bryophytes can form biological soil crusts, enhance topsoil stability, reduce wind erosion, water erosion and fertility loss. According to a research, when the bryophyta layer grows thicker, its soil conservation capacity becomes stronger.

Cold and drought endurance. Some of the bryophytes can endure cold and drought. Many species of brophytes grow in the north temperate zone, even frigid zone.An experiment showed that the bryophytes could still grow normally after being baked at high temperature from $40{ }^{\circ} \mathrm{C}$ to $50{ }^{\circ} \mathrm{C}$ [3].

Easy planting and management. Bryophytes require less about substrate, they can absorb moisture and nutrient through rainwater and other non-artificial methods. They can preserve themselves from plant diseases and insect pests. Bryophytes grow fast and have strong capability of acclimatization. According to a research, after some human-caused or forest fires, bryophytes can quickly cover the bare ground and restore the ecological environment [4].

There are many kinds of bryophytes in northern China, for example, there are 62 species of bryophytes in Jinan [5], some of these bryophytes such as Fissidens bryoides, Dicranodontium, Bryum argenteum, can be used for urban landscaping. At present, lawn is commonly used for urban landscaping, but its maintenance cost is high, some maintenance methods may destroy the original ecological balance and cause pollution. The growth conditions of most lawn plants can not fully fit the climate of northern China, however, bryophytes have a strong capability in multiplying and acclimation, and they have not only low planting and maintenance cost, but also good landscaping effect. Therefore, bryophytes can instead some kinds of traditional landscaping plants, and they will have good prospects for application. Glass pumice can be used as a good substrate for bryophytes growth.

\section{Features and advantages of glass pumice}

Glass pumice is made from waste glass. There are many types and colors to choose from. Compared with ceramsite and other water-storage materials, glass pumice has advantages of light weight, high compressive strength, good capacity of water holding and storage, stable physical and chemical properties and so on. Glass pumice is a kind of high quality soil conditioner, and can also be used as a good growth substrate for bryophytes. 
Glass pumice has been widely used as a roof planting substrate, while the roof vegetation is mainly dominated by grass. Using bryophytes instead of grass on impounded roof can increase poundage and reduce cost.

\section{The application of bryophytes and glass pumice in landscape design}

Bryophytes have been used for landscaping in European and American since 1930s. In Japan, bryophytes have been used for landscaping in Saihoji Temple. In China, only in the southern city Hangzhou, a large-scale bryophyte landscape was built in West Lake Park a few years ago. There is still no bryophyte landscape in northern China until now. Here are some suggests on the application of bryophytes and glass pumice in northern landscape design.

Wetlands landscaping. Bryophytes can be used as ground vegetation in the riparian zone, or combine with aquatic plants such as reeds and cattails for ornament. Glass pumice used as substrate can also be used as natural water bank to enrich the landscape gradations. Bryophytes and glass pumice can be designed as ecological floating islands to enrich the waterscape view.

Roof landscaping. Bryophytes and glass pumice can be combined with small flowering shrubs and perennials to decorate pergola or outdoor furniture that on the terraces. In small terraces, bryophytes, glass pumice and sedum can be used to create micro landscape. Bryophytes and their glass pumice substrate can also be used as roof coverings, such as form a figure-ground relation or pattern on the roof.

Low elevation greenbelt landscaping. In recent years, many northern cities have begun to build low elevation greenbelt. Bryophytes and glass pumice can be used in designing dry creek, grass land, waterscape, rainwater garden and other kinds of low elevation greenbelt, or be used to hide the drainage entrances of the low elevation greenbelt. They can also be used for sunken landscape, such as sunken square or dry landscape, etc.

Flower or tree pool design.Bryophytes has the characteristics of shade tolerance and can accept tree crown eluviation, they can absorb nutrients and store the nutrients in the soil, so they can instead of traditional tree pool grates. Combine with glass pumice substrate, they could conserve water and nutrient for soil in the tree pool, and make a better landscape view.

Pavement design. Combine with pebbles, gravel and other materials, bryophytes and glass pumice can be designed as contrasting terrace steps or footpath in different colors and texture of the pavement. Meanwhile this combination can be used to constitute pattern or bedim pavement edge. Bryophytes and glass pumice can also be used to fill the gaps between kerbstones or terrace steps, that could make the pavement edge lines become soft and active to create a natural, irregular visual effect.

Vertical plane decoration. Bryophytes can grow in vertical plane. So bryophytes and glass pumice can be designed as words or pattern to decorate building surface, feature walls, stone tablets and other suitable vertical surface. Glass pumice can also be used with other stone material to make stone gabions. Be planted with bryophytes, these stone gabions could be used as hedge or feature wall to emphasize landscape function, 
like separating space or guiding directions, ect.

\section{Conclusions}

The above analysis shows that the bryophytes have strong adaptability, and the glass pumice can be used as their planting substrate. Using bryophytes and glass pumice for landscaping is beneficial to improve both landscape and ecological effect. Landscape design can be considered from six aspects: wetlands, roof, low elevation greenbelt, flower or tree pool, pavement and vertical plane decoration. These applications have good expectations, and provide an important reference for ecological landscape design based on LID mode in northern China.

\section{References}

[1] Zuntian.Zhao, Tong Cao, in: Flora Bryophytorum Shandong Sinicorum, Shandong science and technology Publishers (2000).

[2] Xinbo Zeng: Study on the Fuction of Siol and Water Conservation of Bryophyta Layer, (Journal of Soil and Water Conservation,China 1995).

[3]Lung Xuezhan, Cao Lintao, Zhou Kunlun: Study on bryophyte:growth habit and its applicability in ecological slope protection, (Environmental Science\& Technology, China 2015).

[4]Smith A J E, in: Bryophyte Ecology, Champan Publishers (1982).

[5] Ren Zhaojie,Huang Zhengli, LI Lin and Zhao Zuntian: Bioindication of bryophytes to environmental quality of Jinan, (Shandong Science, China 2011). 